\title{
FARKLI TAHIL VE BAKLIYYAT UNLARI ILEE ÜRETİLEN TARHANALARIN FİZİKOKİMYASAL, REOLOJİK VE DUYUSAL NİTELİKLERİ
}

\author{
Müge Hendek Ertop ${ }^{*}$,Rabia Atasoy ${ }^{2}$ \\ ${ }^{1}$ Kastamonu Üniversitesi, Mühendislik ve Mimarlık Fakültesi, Gıda Mühendisliği Bölümü, Kastamonu, Türkiye \\ ${ }^{2}$ Kastamonu Üniversitesi, Fen Bilimleri Enstitüsü, Gıda Mühendisliği Bölümü, Kastamonu, Türkiye
}

Geliş / Received: 07.01.2019; Kabul / Accepted: 19.07.2019; Online bask1 / Published online: 11.08.2019

Hendek Ertop, M., Atasoy, R. (2019). Farklı tahıl ve bakliyat unları ile üretilen tarhanaların fizikokimyasal, reolojik ve duyusal nitelikleri. GID $A$ (2019) 44 (5): 781-793 doi: 10.15237/gida.GD19018

Hendek Ertop, M., Atasoy, R. (2019). Physicochemical, rheological and sensory properties of tarhana samples produced by different cereal and pulse flours. GIDA (2019) 44 (5): $781-793$ doi: 10.15237/gida.GD19018

\section{ÖZ}

Bu çalş̧mada, geleneksel fermente bir gida olan tarhananın yapımında buğday unu yerine, nohut, fasulye, mısır, pirinç, karabuğday ve mercimek unu kullanımının fizikokimyasal, reolojik ve duyusal nitelikler üzerindeki etkileri araştırılmıştır. Tarhana ve unların renk, su ve yağ tutma kapasitesi, viskozite, rutubet, $\mathrm{pH}$, toplam asitlik, protein, yağ, kül, karbonhidrat, mikrobiyolojik ve duyusal analizleri yapılarak özellikleri belirlenmiştir. Formülasyon ve diğer hammaddeler sabit tutulduğunda tarhana nitelikleri kullanılan unun özelliklerinden önemli düzeyde etkilenmiştir. Tarhanalarda en yüksek kül miktarı fasulye tarhanasında (\%5.18 \pm 0.01$)$,protein miktarı kırmızı mercimek tarhanasında (\%28.19 \pm 0.74$)$ ve yağ oranı mısır tarhanasında (\%9.55 \pm 0.56$)$ bulunmuştur. Aynı süre ve koşullarda fermantasyona tabi tutulan tarhanaların $\mathrm{pH}$ değerleri arasındaki fark mısır hariç istatistiksel olarak önemsiz $(P>0.05)$ bulunmuştur. Tarhana kurutma prosesinin maya, toplam aerobik ve toplam anaerobik mikroorganizma sayllarında azalmaya neden olduğu ancak kuru tarhanalarda mikrobiyel canlliğın devam ettiği belirlenmiştir. Tarhanaların, kullanılan tahıl ve baklagil ununa göre teknolojik ve reolojik niteliklerinin değisstiği tespit edilmiştir. Tarhanaların duyusal nitelikleri değerlendirildiğinde örneklerin genel kabul edilebilirliği arasında istatistiksel fark olmadığı belirlenmiştir.

Anahtar Kelimeler: Tarhana, fermente gidalar, laktik asit bakterisi, duyusal özellikler

\section{PHYSICOCHEMICAL, RHEOLOGICAL AND SENSORY PROPERTIES OF TARHANA SAMPLES PRODUCED BY DIFFERENT CEREAL AND PULSE FLOURS}

\begin{abstract}
In this study, the use of chickpea, bean, corn, whole rice, buckwheat and lentil flours instead of wheat flour has been evaluated in terms of physicochemical, rheological and sensory properties for the tarhana. The color, water and oil binding capacity, viscosity, moisture, $\mathrm{pH}$, total acidity, protein, fat, ash, carbohydrate, microbiological and sensory properties of the tarhana samples were examined. When the formulation and other raw material qualities were kept constant, the properties of tarhana were significantly affected by the type of flour. The highest ash content in the bean tarhana $(5.18 \pm 0.01 \%)$, the highest protein content in the red lentil tarhana $(28.19 \pm 0.74 \%)$ and the highest oil content in the corn tarhana $(9.55 \pm 0.56 \%)$ were determined. $\mathrm{pH}$ value of the tarhana samples, which were fermented under the same conditions, were found to be statistically insignificant $(P>0.05)$ except the corn tarhana. Although the drying process caused a decrease in the number of yeast, total aerobic and anaerobic microorganisms, the microbial viability still remained in dry tarhana samples. The technological and rheological qualities of the tarhana samples changed according to flour types. However, there wasn't a significant difference among the overall acceptability of the samples according to sensory evaluation.
\end{abstract}

Keywords: Tarhana, fermented foods, lactic acid bacteria, sensory properties

\footnotetext{
*Yazışmalardan sorumlu yazar/ Corresponding Author

\muge_ertop@hotmail.com, @ (+90) 5326678240

岛 $(+90) 3662802968$
} 


\section{GİRIŞ}

Tarhana TSE 2282'de, buğday unu, buğday kırması, irmik veya bunların karışımı ile yoğurt, yeşil veya kırmızıbiber, tuz, kuru soğan, domates, tat ve koku verici, sağllğa zararsız bitkisel maddelerin karıştırilip fermente edildikten sonra kurutulmas1, ögütülmesi ve elenmesiyle elde edilen bir gıda maddesi olarak tanımlanmıştır (Anonim, 2004; Duran, 2017).

Ülkemizin en önemli geleneksel fermente ürünlerinden olan tarhana, yüksek besinsel kaliteye sahip bir gidadır. Kolay sindirebilir ve besinsel (mineral, protein, vitamin ve organik asitler) maddeler açısından zengin olduğu için insan sağllğı açısından önemli bir yere sahiptir (Özcelik vd., 1997; Özdemir vd., 2007). Geleneksel tarhana yapımı, bileşiminde kullanılan maddelerin karışımı ve fermentasyon süresi ile birlikte toplam 5-7 gün sürmektedir. Türkiye'nin farklı bölgelerine göre tarhana üretimi ve isimleri değişiklik göstermektedir. Tarhana formülasyonlarına yöresel olarak farklı tahıl ve ürünleri eklenebilmektedir. Tarhana un ve yoğurt ana hammaddeleri sayesinde temel aminoasitler yönünden birbirini tamamlarken, iyi bir protein ve vitamin kaynağı olmaktadır. Mineraller açısından zengin ve beslenme açısından büyük öneme sahiptir. Tarhana zenginleştirilmeye açık bir gıdadır (Bilgiçli ve Ibanoglu, 2007). Kuru formuyla cips şeklinde veya sulandırılmış kuru tozun kaynatılmasıyla çorba şeklinde tüketilmektedir (Tamer vd., 2007; Kumral, 2015).

$\mathrm{Bu}$ çalısma ile tahıl ve bakliyat unlarının hammadde olarak kullanımıla günümüz tüketicisinin fonksiyonel, doğal alternatif ürün beklentisine hitap edecek, geleneksel fermente tarhanaya alternatif bir ürün grubu kazandırılması amaçlanmıştır. $\mathrm{Bu}$ amaçla tarhana yapımında buğday unu yerine zengin protein ve besinsel içeriğe sahip nohut, fasulye, mısır, kepekli pirinç, karabuğday ve kırmızı mercimek unlarının kullanım olanaklarını araştırılmış, ürünlerinin fizikokimyasal, teknolojik, reolojik ve duyusal özelliklerini tespit edilerek karşılaştırılmıstır.

\section{MATERYAL VE YÖNTEM}

Araştırmada kullanılan nohut, fasulye, kırmızı mercimek, kavuzlu pirinç, karabuğday ve misır Kastamonu'da yerel bir firmadan sağlanmış ve Kastamonu İhsangazi ilçesinde taş değirmende ögütülerek unları elde edilmiştir. Üretimde kullanılan diğer hammaddeler ve sebzeler (yoğurt, soğan, biber, domates, dereotu ve tuz) yerel bir marketten temin edilmiştir.

\section{Tarhana Örneklerinin Hazırlanması}

Tarhana üretiminde spontan kademeli fermantasyon yöntemine dayanan geleneksel tarhana yapım metodu uygulanmıştır. Formülasyonda yoğurt $(400 \mathrm{~g})$, taze nane $(20 \mathrm{~g})$, kırmızı (50g) ve yeşil $(50 \mathrm{~g})$ biber, tuz $(30 \mathrm{~g})$ ve dereotu (5g) karıştırilarak 24 saat $30^{\circ} \mathrm{C}$ 'de fermente edilmiş, parçalanmış domates $(150 \mathrm{~g})$ ve soğan $(100 \mathrm{~g})$ ilave edilerek $30^{\circ} \mathrm{C}$ 'de 24 saat daha fermentasyona bırakılmıştır. Un (400g) ilave edilerek karıştırılmış, ağzı hava alacak ancak kurumayacak şekilde kapatılarak ve her 12 saatte karıştırlarak 2 gün süreyle fermantasyona devam edilmiştir. $\mathrm{pH} 4.0 \pm 0.5$ düzeyine gelmesi ve yapıda $\mathrm{CO}_{2}$ oluşması ile fermantasyona son verilmiştir. Daha sonra kurutma $\left(50^{\circ} \mathrm{C}\right)$, parçalama $(1-2 \mathrm{~cm})$, öğütme ve eleme prosesleri uygulanmıştır.

\section{Fizikokimyasal Özellikler}

Un ve tarhana numunelerinde rutubet, protein, kül ve yağ analizleri AACC (2000) standart metotlara göre yapılmıştır (Rutubet No:44-15A, Kül No:08-01, Yağ No:30-25). Örneklerin serbest azot miktarı analizinde Kjeldahl metodu (AACC No:46-12) kullanılmış, protein miktarlarının hesaplanmasinda ise kırmızı mercimek, nohut ve fasulye ununda 6.25 , kepekli pirinç ve mısır unları için 5.95 ve karabuğday için 5.70 faktörü kullanılmıştır. Toplam miktarın 100'den çıkartılması ile toplam karbonhidrat oranı (\%) hesaplanmıştır.

\section{pH ve Toplam Titrasyon Asitliği (TTA)}

Tarhana örneklerinden $10 \mathrm{~g}$ alınarak $90 \mathrm{ml}$ distile su ile tamamlanarak 3 dak boyunca karıştırıcı ile karıştırılmış ve çözelti filtre kağıdından (Whatman 30) süzülmüştür. Çözeltinin $\mathrm{pH}^{\prime} 1$ daha sonra bir dijital pH metre (Heidolph, Germany) kullanılarak ölçülmüsstür. Elde edilen çözelti $0.1 \mathrm{M} \mathrm{NaOH}$ ile 
titre edilerek TTA belirlenmiş, laktik asit (\%) olarak ifade edilmiştir (Nes vd., 1996).

\section{Laktik Asit Bakterileri (LAB)ve Maya Sayımı} Tarhana hamurlarında ve toz tarhanalarda $L A B$ ve maya sayımı yapılmış, bu amaçla $10 \mathrm{~g}$ örnek $90 \mathrm{~mL}$ steril fizyolojik tuzlu suda (SFS) homojenize edilmiştir. $\mathrm{Bu}$ şekilde hazırlanan $10^{-1}$ lik seyreltiden 1'er mL 9 mL'lik SFS'lere aktarlarak diğer seyreltmeler yapılmıştır. Uygun dilüsyonlardan $0.1 \mathrm{~mL}$ alınarak, MRS Agara, M17 Agar ve YGC agara (yeast extrakt glucose chloromfenicol agar)yayma kültür yöntemiyle ekim yapılmış ve 2 gün süreyle inkübe edilmiştir. İnkübasyon sonunda petri kutularındaki koloniler sayılmıştır (Erkan, 2004; Hendek Ertop, 2017).

\section{$\operatorname{Renk}\left(L^{*}, a^{*}, b^{*}\right)$}

Bakliyat, tahil unları ve tarhana numunelerinin kolorimetrik (Minolta, Co.,Ltd, Osaka, Japan) olarak renk ölçümleri yapılmıştır. Ölçümler 3 noktadan yapılarak değerlerin ortalaması alınmış ve renk parametreleri $\left(L^{*}, a^{*}, b^{*}\right)$ belirlenmiştir. Ölçüm verilerinin Eşitlik (1)'in kullanımı ile elde edilen renk farklilığ1 $\left(d \mathrm{E}_{a b}\right)$ değerleri de hesaplanmıştır (Bilgiçli, 2009a).

$$
d E_{a b}^{*}=\sqrt{(d L)^{2}+(d a)^{2}+(d b)^{2}}
$$

\section{Su tutma (STK) ve Yağ tutma kapasitesi (YTK)}

Su ve yağ tutma kapasitesi tarhanada gram başına emilen su veya yağ gramı olarak ifade edilmiş, hesaplama için aşağıdaki eşitlikler kullanılmıştır (Hayta vd., 2002; Bilgiçli, 2009a). Tüm analizler 3 paralel yapilmıştır.

$$
\begin{aligned}
& \operatorname{STK}(\mathrm{ml} / \mathrm{g})=\frac{\text { Ağırlık }}{\text { sediment }- \text { Ağırlık }_{\text {örnek }}} \\
& Y T K(\mathrm{ml} / \mathrm{g})=\frac{\text { Ağırlık }}{\text { sediment }-\mathrm{Ağırlık}_{\text {örnek }}}
\end{aligned}
$$

\section{Viskozite}

$20 \mathrm{~g}$ toz tarhana $200 \mathrm{ml} 20^{\circ} \mathrm{C}$ 'de saf suyla $10 \mathrm{dak}$ karıştırılmış, sürekli karıştırılarak orta ateşte 10 dak süreyle kaynatılmış ve nişasta jelatinizasyonu tamamlanmıştır. Çorba durumundaki tarhananın viskozitesi $60^{\circ} \mathrm{C}$ 'de rotasyonel viskozimetre (Fungilab Expert L viscometer, ABD-spindel no:3) kullanilarak 5, 20, 30, 60 ve 100 rpm'de İbanoglu vd. (1995) ve Hayta vd. (2002)'ye göre ölçülmüştür.

\section{Duyusal Analiz}

Tarhana örneklerinden hazırlanan çorbalar duyusal analize tabi tutulmuştur. Tarhana, ekşi hamur gibi asidik fermente ürünleri tüketen 10 panelist belirlenmiştir. Tarhana çorbalarını renk, tat, koku, genel yeme hissi ve kıvam açısından değerlendirerek 9 puanlı hedonik skala ile puanlamaları istenmiştir. Tarhana çorbası $40 \mathrm{~g}$ tarhana ve $500 \mathrm{ml}$ su karışımının sabit karıştırma ile 10 dak kaynatılmasıyla hazırlanmış (Erkan vd., 2006) ve 25-38 yaş aralıklarında dört bayan, altı erkek paneliste rastgele düzende, $60^{\circ} \mathrm{C}$ 'de sunulmuştur

\section{İstatistiksel analiz}

Deneylerden elde edilen analiz sonuçlarının istatistiksel değerlendirmesi SPSS 20.0.1 (SPSS Inc., Chicago, Illinois, US) kullanılarak yapılmıştır. Veriler çoklu varyans analizine (ANOVA) tabi tutularak örneklerin veri ortalamaları arasındaki fark $P<0.05$ anlamlllık düzeyinde Tukey çoklu karşılaştırma testi yapılarak belirlenmiştir. Aynı örnek için kurutma prosesinin tarhana mikrobiyel canlıllğı üzerindeki etkisini belirlemek, hammadde ve tarhana örneklerine ait verilerin ikili karşılaştırılması amacıyla da bağımsız Student- $t$ testi kullanılmış, veriler $\% 5$ önem düzeyinde değerlendirilmiştir. Duyusal analiz sonuçlarının değerlendirilmesinde Kruskal Wallis testi kullanılmış ve her bir duyusal nitelik açısından örnekler arasindaki fark \%5 önem düzeyinde test edilmiştir.

\section{ARAŞTIRMA BULGULARI Fizikokimyasal özellikler}

Kurutulmuş toz tarhana TS 2282 standardına göre en çok \%10 nem içeriğine sahip olmalıdır (Anonim, 2004; Şimşek vd., 2012). Unların, yaş tarhanaların ve kurutulmuş toz tarhanaların rutubet değerleri Şekil 1'de verilmiştir. Hammadde olarak kullanılan unlardan en yüksek rutubet içeriği kepekli pirinç (\%12.34) ve mısır ununda (\%12.02), en düşük rutubet değeri kırmızı mercimek (\%9.21) ununda olduğu tespit edilmiştir. Yaş tarhanalarda rutubet miktarı 
ortalama \%52.30 iken, kurutulmuş toz tarhanalar da ortalama \%6.33 düzeyinde bulunmuştur. Tahıl ve baklagil unlarıyla yapılan çalışmalarda kırmızı mercimek ununun \%7.97 (Kohajdová vd., 2013), kepekli pirinç ununun \%12.30, nohut ununun \%9.14 (Özmen, 2011) rutubet içeriğine sahip olduğu bildirilmiştir.

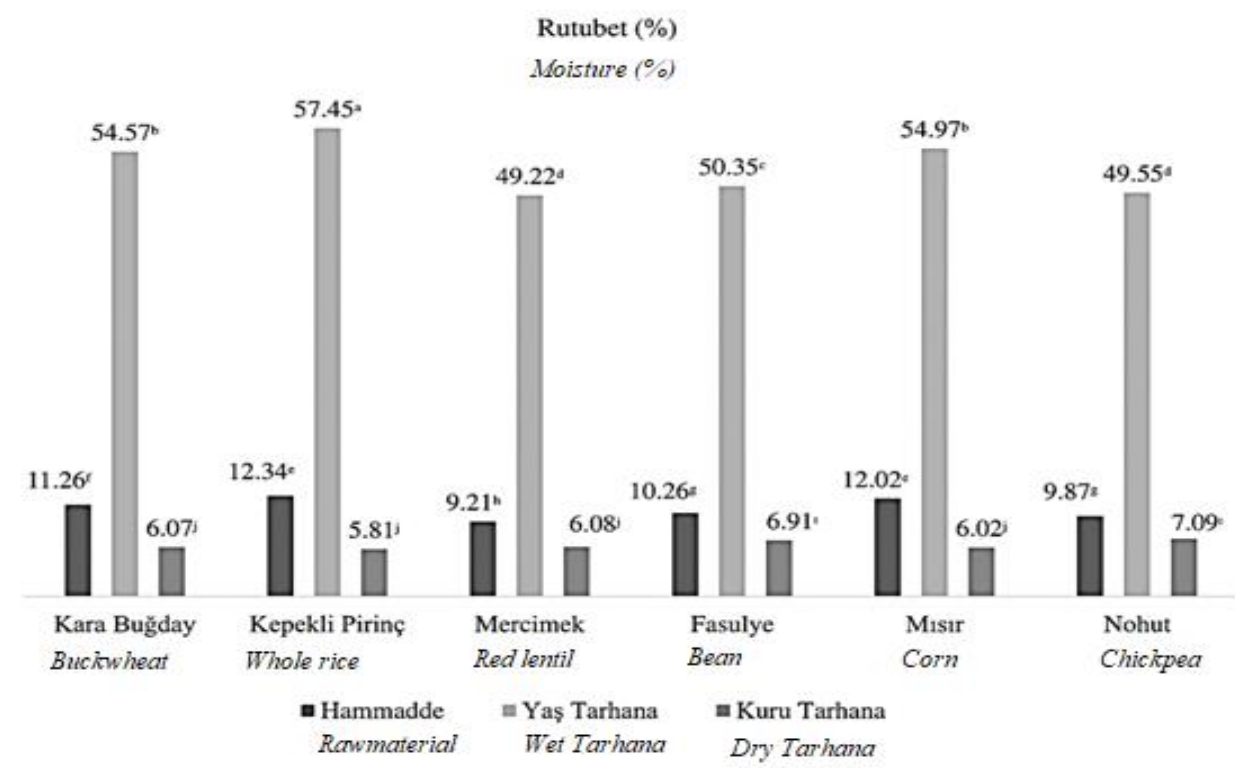

*Birbirinden farklı harfler, veriler arasında istatistiksel olarak önemli fark $(P<0.05)$ olduğunu göstermektedir *Different letters indicate significant differences $(P<0.05)$ between the samples

Şekil 1. Un, yaş ve kuru tarhana örneklerinin rutubet değerleri

Figure 1. Moisture values of wet and dry tarhana, and flour samples

Tahıl ve baklagil unu katkilı tarhanaların ve unlarının bazı fizikokimyasal özellikleri Çizelge 1'de verilmiş, aralarındaki farklılıklar istatistiki önem $(P<0.05)$ düzeyinde incelenmiştir. TS 2282 tarhana standardına göre, tarhanada kuru madde üzerinden en az $\% 12$ protein bulunmalıdır. Tarhana içeriğindeki protein tahıl ve baklagil unlarının yanı sıra yoğurttan da gelmektedir. Unlarda en yüksek protein kırmız1 mercimek $(\% 26.53)$ ve fasulye ununda (\%19.53), tarhana numunelerde ise paralel olarak kırmızı mercimek tarhanas1 (\%28.19) ve fasulye tarhanasinda (\%21.63) tespit edilmiştir. Erkan vd. (2006), tarafindan yapilan çalışmada, buğday unu ile tarhana numunelerinde ortalama \%15.10, arpa tarhanasinda ortalama \%10.10, buğday ve arpa unları karışımı tarhana numunelerinde $\% 13.60$ protein oranı tespit edilmiştir. Tamer vd. (2007) yaptıkları çalışmada farklı tarhana örneklerinin protein oranının \%6.77-28.55 arasında değiştiğini ve ortalama $\% 14.93$ olduğunu belirtmişlerdir.
Farklı içeriklere sahip tarhana numunelerinde yapılan çeșitli çalışmalarda numunelerin protein miktarları farklı düzeylerde bulunmuștur (Köse ve Çağınd1, 2002; Göçmen vd., 2003; Erkan, 2004; Erkan vd., 2006; Özdemir vd., 2007; Bilgiçli, 2009a). Yapılan çalışmalarda bu farklıllğın esas olarak tarhana formülasyonundaki yoğurt tipi ve miktarından (Yücecan vd., 1988; Temiz ve Pirkul, 1991) ve kullanılan un çeşidi ve miktarından kaynaklandığı bildirilmiștir (Öner vd., 1993; Köse ve Çağınd1, 2002). Bu çalş̧mada ise tüm formülasyonlarda yoğurt tipi ve miktarı değişmemiş ve protein değerlerindeki değişimin kullanılan tahil ve baklagil unlarından kaynaklandığ tespit edilmiştir.

Hammadde olarak kullanılan unlar arasında en yüksek yağ miktarı misır ununda (\%6.33), en düşük kepekli pirinç ununda (\%1.63) olduğu belirlenmiştir. Tarhana formülasyonunda un haricindeki bütün bileşenler aynı miktarda 
kullanıldığından, tarhana örneklerindeki yağ miktarı farklılığının kullanılan unlardan kaynaklandığ1 söylenebilir. Unlara paralel olarak, tarhana örneklerinde de en yüksek yağ içeriği mısır unlu tarhanada (\%9.55), en düşük yağ miktarı ise kepekli pirinç unlu tarhanada (\%6.39) olduğu tespit edilmiştir. Yapılan farklı çalışmalarda, buğday unu içeren tarhanada \%3.40, arpa unlu tarhana numunelerinde \%3.39 (Erkan vd., 2006), kinoa unu içeren örneklerde \%8.04 ve farklı tarhana örneklerinde ortalama \%5.4 yağ içeriğinin olduğu belirtilmiştir (Kıtan, 2017). Dağlıoğlu (2000) tarafindan yapılmış tarhana çalışmasında, yağ içeriğinin tarhana bileşenlerine bağlı olarak \%1.6-18.2 arasında değişebileceğini belirtilmiştir.

Tarhana örneklerinin karbonhidrat miktarları (Çizelge 1) arasında da istatistiksel olarak önemli fark olduğu tespit edilmiştir $(P<0.05)$. Unlar arasında en yüksek mısır (\%73.75) ve karabuğday ununda (\%72.84); tarhanalarda en yüksek misır (\%70.80) tarhanasinda ve kepekli pirinç tarhanasinda (\%70.24) tespit edilmiştir. Karbonhidrat miktarları doğrudan proteinle ilişkili olduğundan protein miktarı yüksek unlarda ve tarhanalarda karbonhidrat değerleri düşük olarak bulunmuştur. Siyamoğlu (1961) Türkiye'nin değişik bölgelerinden tarhana numuneleri toplayarak aralarındaki farklılıkları belirlemiş, tarhananın ortalama \%60'nın karbonhidrat olduğunu tespit etmiştir. Yörükoğlu (2012), Maraş tarhanası üzerinde yapmış olduğu çalışmada ise tarhananın karbonhidrat içeriğini \%72.67-78.59 aralığında saptamıştır.

Tarhanaların aynı formülasyon ve hammaddeler ile hazırlandığı, ayrıca kullanılan un ve tarhanaların yağ, protein ve karbonhidrat bileşenleri göz önünde bulundurulduğunda, tarhana temel bileşiminin kullanılan undan kaynaklandığı söylenebilir.

Tahil ve baklagil unlu tarhanaların ve unlarının $\mathrm{pH}$ ve asitlik dereceleri Çizelge1'de verilmiştir. Fermente bir ürün olan tarhanaların, unlara göre $\mathrm{pH}$ değerlerinin daha düşük, TTA'nin daha yüksek olduğu saptanmıştır. Aynı süre ve koşulda fermantasyona tabi tutulan tarhanaların $\mathrm{pH}$ değerleri genel olarak birbirine yakın olduğu tespit edilmiş mısır haricinde diğer örnekler arasındaki fark istatistiki olarak önemli $(P>0.05)$ bulunmamışır.

Tarhana TS 2282 standardına göre $\mathrm{pH}$ ile ilgili herhangi bir sinırlama bulunmamaktadır. Ancak farklı çalışmalarda kabul edilebilir tarhana $\mathrm{pH}$ değerlerinin 3.8-4.2 aralığında olduğu belirtilmektedir (Dağlıoğlu, 2000; Tamer vd, 2007). Yapılan birçok araştırmada buğday unu ile yapılan tarhananın $\mathrm{pH}$ değeri 4.59 , asitlik değeri $\% 1.4$, buğday ve arpa unlu tarhana örneklerinin $\mathrm{pH}$ değerinin ortalama 4.81 asitlik değerinin 1.2 (Erkan vd., 2006), karayemiş içeren tarhana örneklerinin ise $\mathrm{pH}$ değerlerinin ortalama 3.63 asitlik değerinin ise \%0.85 (Tarakçı vd., 2013) olduğu belirlenmiştir. Tarhanalardaki asitlik değişiminin uygulanan proses ve fermantasyon koşulları kadar kullanılan hammaddelerden ve bu hammaddelerin mikrobiyota tarafindan fermente olabilirliğinden de etkilendiği düşünülmektedir.

\section{Tarhanaların Mikrobiyolojik Nitelikleri}

Kurutma prosesinin tarhana mikrobiyotas1 üzerindeki etkisini tespit etmek amaciyla YGC agarda maya, MRS agarda anaerobik LAB, M17 agarda ise aerobik LAB sayımları gerçekleştirilmiştir. Fermantasyon süresi sonunda yaş tarhanalarda ve kurutma işlemi sonunda da kuru tarhana örneklerinde yapılan mikrobiyolojik sayımlarda elde dilen maya, toplam aerobik ve toplam anaerobik LAB sayıları Çizelge 2'de verilmiştir. Tarhana örneklerinin kurutma öncesi ve sonrasi toplam aerobik, anaerobik LAB ile maya sayım sonuçları arasındaki farklar istatistiki olarak önemli $(P<0.05)$ bulunmuştur. Toplam aerobik LAB yaş örneklerde en yüksek misır tarhanasinda $89.10^{5} \mathrm{kob} / \mathrm{g}$, kuru örneklerde ise fasulye tarhanasinda $67.10^{3} \mathrm{kob} / \mathrm{g}$ tespit edilmiştir. Toplam anaerobik LAB ise en yüksek, yaş ve kuru kırmızı mercimek tarhanalarında $69.10^{5} \mathrm{kob} / \mathrm{g}$ $34.10^{4} \mathrm{kob} / \mathrm{g}$ tespit edilmiştir. Maya ise en yüksek yaş ve kuru mercimek tarhanalarında (87.104 $43.10^{3} \mathrm{kob} / \mathrm{g}$ ), en düşük ise yaş ve kuru nohut tarhanalarında $\quad\left(39.10^{4}-39.10^{2} \mathrm{kob} / \mathrm{g}\right) \quad$ tespit edilmiştir. 
Çizelge 1. Un ve kuru tarhana örneklerinin bazı fizikokimyasal özellikleri Table1. Physicochemical properties of flour and dry tarbana samples

\begin{tabular}{|c|c|c|c|c|c|c|c|}
\hline & & $\begin{array}{l}\text { Protein } \\
(\mathrm{g} / 100 \mathrm{~g}) \\
\text { Protein } \\
(\mathrm{g} / 100 \mathrm{~g})\end{array}$ & $\begin{array}{c}\text { Kül } \\
(\mathrm{g} / 100 \mathrm{~g}) \\
\text { Ash } \\
(\mathrm{g} / 100 \mathrm{~g})\end{array}$ & $\begin{array}{c}\text { Yağ } \\
(\mathrm{g} / 100 \mathrm{~g}) \\
\text { Fat } \\
(\mathrm{g} / 100 \mathrm{~g})\end{array}$ & $\begin{array}{l}\text { Karbonhidrat } \\
(\mathrm{g} / 100 \mathrm{~g}) \\
\text { Carbohydrate } \\
(\mathrm{g} / 100 \mathrm{~g})\end{array}$ & $\begin{array}{l}\mathrm{pH} \\
\mathrm{pH}\end{array}$ & $\begin{array}{l}\text { TTA } \\
(\%) \\
T T A \\
(\%)\end{array}$ \\
\hline \multirow{6}{*}{ 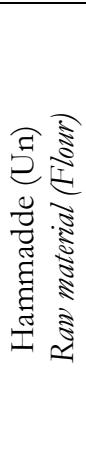 } & $\begin{array}{l}\text { Karabuğday } \\
\text { Buckwheat }\end{array}$ & $10.54 \pm 0.45^{\mathrm{d}}$ & $2.22 \pm 0.03^{\mathrm{d}}$ & $3.13 \pm 0.32^{\mathrm{bc}}$ & $72.84 \pm 0.68^{b}$ & $6.28 \pm 0.03^{a}$ & $1.11 \pm 0.04^{b c}$ \\
\hline & $\begin{array}{l}\text { Kepekli pirinç } \\
\text { Whole rice }\end{array}$ & $7.66 \pm 0.47 \mathrm{e}$ & $1.94 \pm 0.01^{\mathrm{e}}$ & $1.63 \pm 0.45^{c}$ & $76.42 \pm 0.39^{a}$ & $6.03 \pm 0.20^{\mathrm{a}}$ & $0.55 \pm 0.02^{\mathrm{d}}$ \\
\hline & $\begin{array}{l}\text { Mercimek } \\
\text { Red lentil }\end{array}$ & $26.53 \pm 0.37^{a}$ & $2.52 \pm 0.01^{b}$ & $2.45 \pm 0.03^{c}$ & $59.29 \pm 0.46^{\mathrm{d}}$ & $6.32 \pm 0.01^{\mathrm{a}}$ & $1.41 \pm 0.11^{\mathrm{ab}}$ \\
\hline & $\begin{array}{l}\text { Fasulye } \\
\text { Bean }\end{array}$ & $19.53 \pm 0.12^{\mathrm{b}}$ & $3.45 \pm 0.01^{\mathrm{a}}$ & $6.05 \pm 0.78^{a}$ & $60.72 \pm 0.08^{d}$ & $6.11 \pm 0.06^{a}$ & $1.64 \pm 0.09^{a}$ \\
\hline & $\begin{array}{l}\text { Misir } \\
\text { Corn }\end{array}$ & $6.75 \pm 0.35^{\mathrm{e}}$ & $1.16 \pm 0.05^{\mathrm{f}}$ & $6.33 \pm 0.62^{\mathrm{a}}$ & $73.75 \pm 0.49^{\mathrm{b}}$ & $5.89 \pm 0.08^{a}$ & $0.83 \pm 0.04^{\mathrm{cd}}$ \\
\hline & $\begin{array}{l}\text { Nohut } \\
\text { Chickpea }\end{array}$ & $16.63 \pm 0.49^{c}$ & $2.61 \pm 0.02^{\mathrm{b}}$ & $5.46 \pm 0.47^{\mathrm{ab}}$ & $65.44 \pm 0.50^{c}$ & $6.11 \pm 0.05^{a}$ & $1.25 \pm 0.02^{\mathrm{b}}$ \\
\hline
\end{tabular}

(a)

\begin{tabular}{|c|c|c|c|c|c|c|c|}
\hline \multirow{6}{*}{ 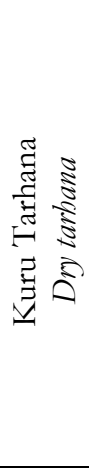 } & $\begin{array}{l}\text { Karabuğday } \\
\text { Buckwheat }\end{array}$ & $13.97 \pm 0.10^{c}$ & $4.59 \pm 0.01^{\mathrm{c}}$ & $7.40 \pm 0.54^{a}$ & $67.97 \pm 0.01^{b}$ & $4.32 \pm 0.06^{\mathrm{ab}}$ & $5.48 \pm 0.11^{\mathrm{a}}$ \\
\hline & $\begin{array}{l}\text { Kepekli pirinç } \\
\text { Whole rice }\end{array}$ & $12.99 \pm 0.58^{c}$ & $4.56 \pm 0.03^{c}$ & $6.39 \pm 0.23^{\mathrm{a}}$ & $70.24 \pm 0.38^{\mathrm{ab}}$ & $4.25 \pm 0.13^{\mathrm{ab}}$ & $5.65 \pm 0.13^{\mathrm{a}}$ \\
\hline & $\begin{array}{l}\text { Mercimek } \\
\text { Red lentil }\end{array}$ & $28.19 \pm 0.74^{a}$ & $4.93 \pm 0.01^{\mathrm{b}}$ & $7.29 \pm 0.65^{\mathrm{a}}$ & $53.50 \pm 0.95^{\mathrm{e}}$ & $4.33 \pm 0.01^{\mathrm{ab}}$ & $5.60 \pm 0.04^{\mathrm{a}}$ \\
\hline & $\begin{array}{l}\text { Fasulye } \\
\text { Bean }\end{array}$ & $21.63 \pm 0.12^{\mathrm{b}}$ & $5.18 \pm 0.01^{a}$ & $8.17 \pm 0.98^{a}$ & $58.11 \pm 0.02^{\mathrm{d}}$ & $4.45 \pm 0.04^{a}$ & $4.76 \pm 0.20^{\mathrm{a}}$ \\
\hline & $\begin{array}{l}\text { Misir } \\
\text { Corn }\end{array}$ & $9.59 \pm 0.35^{\mathrm{d}}$ & $4.04 \pm 0.01^{\mathrm{d}}$ & $9.55 \pm 0.56^{a}$ & $70.80 \pm 0.23^{a}$ & $4.03 \pm 0.06^{\mathrm{b}}$ & $4.66 \pm 0.35^{\mathrm{a}}$ \\
\hline & $\begin{array}{l}\text { Nohut } \\
\text { Chickpea }\end{array}$ & $19.28 \pm 0.25^{b}$ & $4.04 \pm 0.02^{\mathrm{d}}$ & $8.92 \pm 0.87^{a}$ & $63.67 \pm 0.09 \mathrm{c}$ & $4.49 \pm 0.01^{\mathrm{a}}$ & $4.72 \pm 0.41^{\mathrm{a}}$ \\
\hline \multicolumn{8}{|c|}{ (b) } \\
\hline \multirow{6}{*}{ 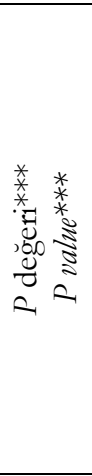 } & $\begin{array}{l}\text { Karabuğday } \\
\text { Buckwheat }\end{array}$ & 0.019 & 0.027 & 0.080 & 0.001 & 0.020 & 0.016 \\
\hline & $\begin{array}{l}\text { Kepekli pirinç } \\
\text { Whole rice }\end{array}$ & 0.069 & 0.007 & 0.031 & 0.039 & 0.046 & 0.016 \\
\hline & $\begin{array}{l}\text { Mercimek } \\
\text { Red lentil }\end{array}$ & 0.267 & 0.003 & 0.085 & 0.104 & 0.003 & 0.006 \\
\hline & $\begin{array}{l}\text { Fasulye } \\
\text { Bean }\end{array}$ & 0.036 & 0.004 & 0.276 & 0.005 & 0.015 & 0.041 \\
\hline & $\begin{array}{l}\text { Misir } \\
\text { Corn }\end{array}$ & 0.078 & 0.002 & 0.110 & 0.050 & 0.021 & 0.058 \\
\hline & $\begin{array}{l}\text { Nohut } \\
\text { Chickpea }\end{array}$ & 0.060 & 0.009 & 0.157 & 0.032 & 0.004 & 0.075 \\
\hline
\end{tabular}

(c)

*Aynı sütundaki birbirinden farklı harfler, veriler arasında istatistiksel olarak önemli fark $(P<0.05)$ olduğunu göstermektedir. *Different letters in the same column indicate significant differences $(P<0.05)$ between the samples **TTA (\%):Toplam titrasyon asitliği; TTA (\%):Total titration acidity

***Unlar ve tarhanaları arasındaki istatistiki ilişkiyi ifade eden $p$ değerleri; *** P values which represents the relationship between flour types and their tarbana samples 
Çizelge 2. Kurutma öncesi ve sonrası tarhana örneklerinde maya ve LAB saylları (kob/g)

Table 2. $L A B$ and yeast count results of the tarbana samples before and after drying $(\log C F U / g)$

\begin{tabular}{|c|c|c|c|c|c|c|c|c|c|}
\hline & \multicolumn{3}{|c|}{$\begin{array}{c}\text { Toplam aerobik } \mathrm{LAB}^{*} \\
(\mathrm{kob} / \mathrm{g}) \\
\text { Total aerobic } \mathrm{L} A B^{* *} \\
(\mathrm{c} f u / g)\end{array}$} & \multicolumn{3}{|c|}{$\begin{array}{c}\text { Toplam anaerobik LAB* } \\
(\mathrm{kob} / \mathrm{g}) \\
\text { Total anaerobic } \mathrm{LAB} \\
(\mathrm{cfu} / \mathrm{g})\end{array}$} & \multicolumn{3}{|c|}{$\begin{array}{c}\text { Maya (kob/g) } \\
\text { Yeast } \\
(c f u / g) \\
\end{array}$} \\
\hline & Yaş & Kuru & $P$ değeri & Yaş & Kuru & $P$ değeri & Yaş & Kuru & $P$ değen \\
\hline $\begin{array}{l}\text { Karabuğday } \\
\text { Buckwheat }\end{array}$ & $76.10^{4 \mathrm{c}}$ & $38.10^{2 \mathrm{~b}}$ & 0.001 & $26.10^{5 a b}$ & $86.10^{3 \mathrm{~b}}$ & 0.003 & $79.10^{4 b}$ & $39.10^{3 \mathrm{ab}}$ & 0.008 \\
\hline $\begin{array}{l}\text { Kepekli pirinç } \\
\text { Whole rice }\end{array}$ & $35.10^{4 \mathrm{c}}$ & $75.10^{2 b}$ & 0.002 & $19.10^{4 b}$ & $79.10^{3 \mathrm{~b}}$ & 0.042 & $69.10^{4 c}$ & $34.10^{3 \mathrm{bc}}$ & 0.010 \\
\hline $\begin{array}{l}\text { Mercimek } \\
\text { Red lentil }\end{array}$ & $52.10^{5 b}$ & $47.10^{3 a}$ & 0.001 & $69.10^{5 a}$ & $34.10^{4 a}$ & 0.010 & $87.10^{4 a}$ & $43.10^{3 a}$ & 0.008 \\
\hline $\begin{array}{l}\text { Fasulye } \\
\text { Bean }\end{array}$ & $14.10^{5 b c}$ & $67.10^{3 a}$ & 0.005 & $22.10^{5 b}$ & $66.10^{3 \mathrm{~b}}$ & 0.003 & $78.10^{4 \mathrm{~b}}$ & $36.10^{3 \mathrm{bc}}$ & 0.009 \\
\hline $\begin{array}{l}\text { Misir } \\
\text { Corn }\end{array}$ & $89.10^{5 a}$ & $45.10^{2 \mathrm{~b}}$ & 0.000 & $93.10^{4 \mathrm{~b}}$ & $87.10^{2 b}$ & 0.001 & $66.10^{4 c}$ & $32.10^{3 c}$ & 0.010 \\
\hline $\begin{array}{l}\text { Nohut } \\
\text { Chickpea }\end{array}$ & $30.10^{3 c}$ & $43.10^{1 \mathrm{~b}}$ & 0.002 & $22.10^{5 b}$ & $58.10^{3 \mathrm{~b}}$ & 0.003 & $39.10^{4 d}$ & $39.10^{2 \mathrm{~d}}$ & 0.002 \\
\hline
\end{tabular}

*Aynı sütundaki birbirinden farklı harfler, veriler arasında istatistiksel olarak önemli fark $(P<0.05)$ olduğunu göstermektedir,

*Different letters in the same column indicate significant differences $(P<0.05)$ between the samples

**LAB: Laktik asit bakterisi; **LAB: Lactic acid bacteria

Genel anlamda yaş tarhanalarda mikrobiyel canlilı fazla iken kurutma işlemine tabi tutulmasina rağmen kuru tarhanalarda da mikrobiyel canlilığın devam ettiği görülmektedir. Dayisoylu vd. (2003) tarafindan Maraş tarhanasında yapılan çalışmada $<10^{4} \mathrm{kob} / \mathrm{g}$ maya, $<10^{4} \mathrm{kob} / \mathrm{g}$ aerobik LAB tespit edilmiştir. Güney Funda (2009), sanayi tipi ve ev yapımı tarhana örnekleri üzerinde yaptı̆̆1 çalışmada, sanayi tipi tarhana örneklerinde $\mathrm{LAB}<10^{2} \mathrm{kob} / \mathrm{g}$, maya $<10^{2} \mathrm{kob} / \mathrm{g}$, ev tipi tarhana örneklerinde ise LAB $<10^{2} \mathrm{kob} / \mathrm{g}$, maya $<10^{2} \mathrm{kob} / \mathrm{g}$ arasında olduğunu bildirmiştir. Kastamonu'nun dokuz farklı yöresinden toplanan geleneksel yaş tarhana örneklerinde ise, $10^{3}-10^{6} \mathrm{kob} / \mathrm{g}$ düzeyinde maya, ayn1 düzeyde aerobik LAB, $10^{5}-10^{6} \mathrm{kob} / \mathrm{g}$ düzeyinde ise anaerobik LAB sayıs tespit edilmiştir (Hendek Ertop vd., 2019). Bu çalışmada elde edilen sonuçlar da literatür bulgularıyla benzerlik göstermektedir.

\section{Tarhana ve Unlarının Bazı Teknolojik Nitelikleri}

Un, yaş tarhana ve kuru tarhana numunelerin de yapılan renk analiz sonuçları Çizelge 3'de verilmiştir. Tablodan görüldüğü üzere unlarda parlaklık $\left(L^{*}\right)$ değerleri yüksekken kuru tarhana örneklerinde parlaklık $\left(L^{*}\right)$ değerlerinde düşüş gözlenmiştir. Kırmızı mercimek hariç diğer tüm hammaddelerin tarhanaya işlenmesi sonucu $a^{*}$ kırmızılık değerinin arttı̆̆1, kırmızı mercimek ununun mevcut kırmızılık değerinin ise düştüğü belirlenmiştir. Misır ve nohut hariç $a^{*}$ değerindeki artışlar istatistiki olarak önemli $\left(\begin{array}{ll}P & <0.05\end{array}\right)$ bulunmuştur. Tüm hammaddelerin tarhanaya işlendikten sonra $b^{*}$ değerlerinde ise artış meydana geldiği tespit edilmiştir. Bu artış özellikle kırmızı mercimek, misır ve nohut örneklerinde istatistiki olarak önemli $(P<0.05)$ bulunmuştur.

Buğday unu ile yapılan bir çalışmada tarhana numunelerinde ortalama $L^{*}, a^{*}, b^{*}$ sirasiyla 75.06; 6.46 ve 20.12 bulmuşlardır (Erkan vd., 2006). Bu çalışmada elde edilen tarhanaların temel renk nitelikleri gerek geleneksel buğday unu tarhanasindan gerekse birbirlerinden önemli düzeyde $(P<0.05)$ farklı bulunmuştur. Bu durum tarhana yapiminda temel hammadde olan unun temel renk karakteristiğinin nihai ürünün rengini de belirlediğini göstermektedir. 
Çizelge 3. Un ve kuru tarhanaörneklerininrenk özellikleri, yağ ve su tutma kapasiteleri Table 3. Color properties, oil and water binding capasity of flour and dry tarbana samples

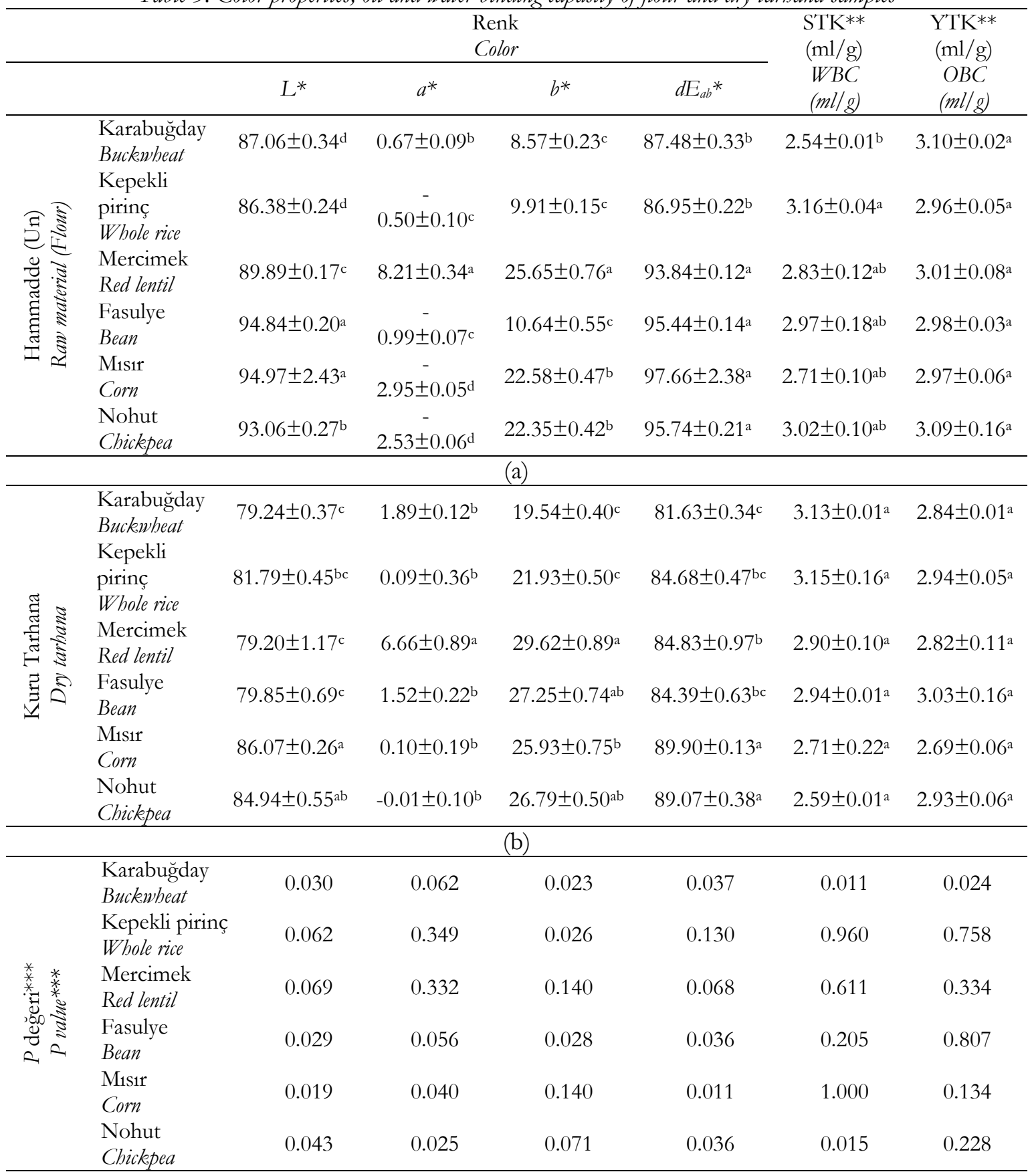

(c)

*Aynı sütundaki birbirinden farklı harfler, veriler arasında istatistiksel olarak önemli fark $(P<0.05)$ olduğunu göstermektedir.

*Different letters in the same column indicates significant differences $(P<0.05)$ between the samples

**STK: Su tutma kapasitesi, YTK: Yağ tutma kapasitesi

** WBC: Water binding capasity, OBC: Oil binding capasity 
Su ve yağ tutma kapasiteleri viskoz özelliği bulunan gidalarda önemli bir fonksiyonel özelliktir. Çizelge 3' de tahıl ve bakliyat unlarının ve tarhanalarının su tutma kapasitesi (STK $\mathrm{ml} / \mathrm{g}$ ) ve yağ tutma kapasitesi (YTK $\mathrm{ml} / \mathrm{g}$ ) değerleri verilmiştir. Unlarda su tutma kapasitesi 2.54 ile $3.16 \mathrm{ml} / \mathrm{g}$ arasında olup en yüksek kepekli pirinç unudur. Yağ tutma kapasiteleri de 2.96 ile 3.01 $\mathrm{ml} / \mathrm{g}$ arasında değişmiş olup karabuğday ununun en yüksek değere sahip olduğu tespit edilmiştir. Tarhana örneklerinde ise STK'nin 2.59 ile 3.15 $\mathrm{ml} / \mathrm{g}$ aralığında, YTK'nin 2.82 ile $3.03 \mathrm{ml} / \mathrm{g}$ arasında olduğu tespit edilmiştir. Tarhanalarda da, unlara paralel olarak en yüksek STK kepekli pirinç unu tarhanasında belirlenmiştir ki bu durumun kepek içeriğinden kaynaklandığı düşünülmektedir. Farklı tarhana numunelerinde yapilan analizlerinde su tutma kapasitelerinin 0.45 ile 1.45 $\mathrm{ml} / \mathrm{g}$ aralı̆̆ında olduğu bildirilmiştir (Hayta vd., 2002). Karabuğday unu ile zenginleştirilerek yapilan tarhanada su tutma kapasitesinin $0.50-0.63$ $\mathrm{ml} / \mathrm{g}$, yağ tutma kapasitesinin 3.54-4.59 ml/g arasında değiştiği belirtilmiş ve karabuğday unu oranı artıkça su tutma ve yağ tutma kapasitelerinin arttığ1 tespit edilmiştir (Bilgiçli, 2009b).

Viskozite, reolojik bir nitelik olup çorba tarzında akışkan gıdaların en önemli ayırt edici özelliklerindendir. Çalışmada farklı tahıl ve baklagil unları ile tarhana üretimi gerçekleşmiştir. Tahıl ve baklagillerde yüksek miktarda nişasta bulunmakta ve bu da kullanıldığ1 gidaların viskozite niteliğini önemli ölçüde etkilemektedir. Nişasta granülleri su ile çözünmediği halde sıcaklık ile muamelesinde çirişlenerek jel yap1 oluştururlar. Fermente bir ürün olan tarhana, nişasta bazlı bir gıda olduğundan kalite niteliğini belirlemede viskozite önemli bir yere sahiptir. Tarhananın diğer bileşenlerini oluşturan yağ ve proteinlerin de viskoz yapıyı etkilediği bildirilmiştir (Kıtan, 2017). Şekil 2'de elde edilen sonuçlara göre özellikle yüksek nişasta içeriğine sahip örneklerin viskozite değerlerinin diğer tarhana örneklerine göre daha yüksek olduğu tespit edilmiştir. En yüksek viskozite değerinin nohut tarhanasinda ve fasulye tarhanasinda olduğu belirlenmiştir.

Tarhana numunelerinde genel olarak rotasyonel hıza ve kayma hızına (Şekil 2) karşılık viskozitenin düştüğü belirlenmiştir. Siv1 g1da numunelerinde genel olarak kayma kuvveti arttıkça viskozitesinde değişim gözlenmektedir. Akış davranışlarının değişimleri sıvı gıdaların içeriğine göre değişmekte ve bu tür akışkanlara 'Non-Newtonian' veya 'ideal olmayan' akışkanlar denilmektedir. Bu çalışmada tüm tarhana numunelerine uygulanan kayma hızına karşın viskozitelerinin düştüğü görülmektedir ve bu da tarhana numunelerinin hepsinin Non-Newtonian akış karakterine sahip olduğunu göstermektedir (Geankoplis, 1983; Erbaş vd., 2005).

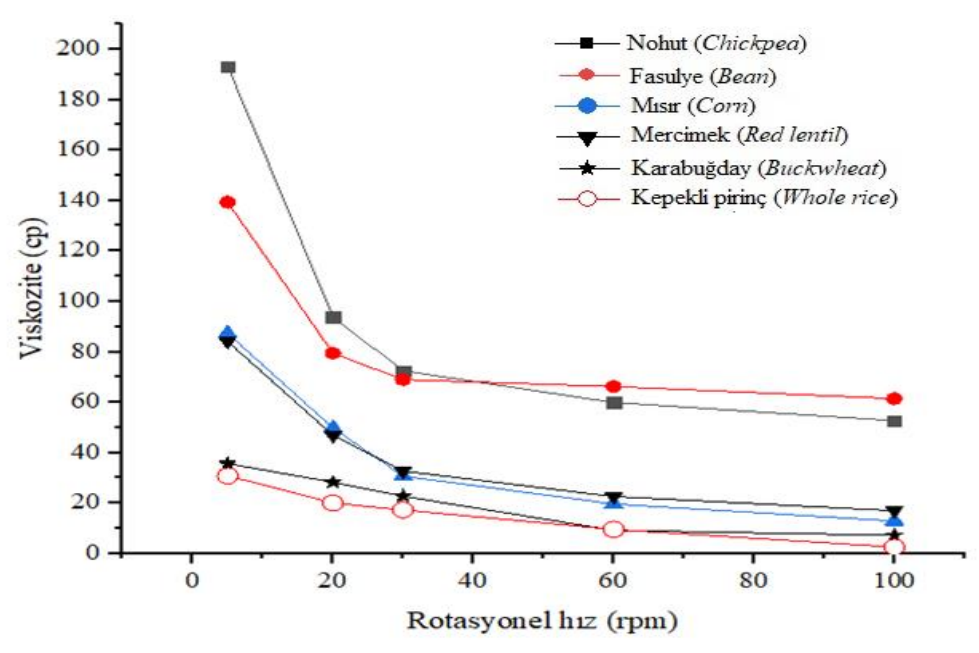

(a) 


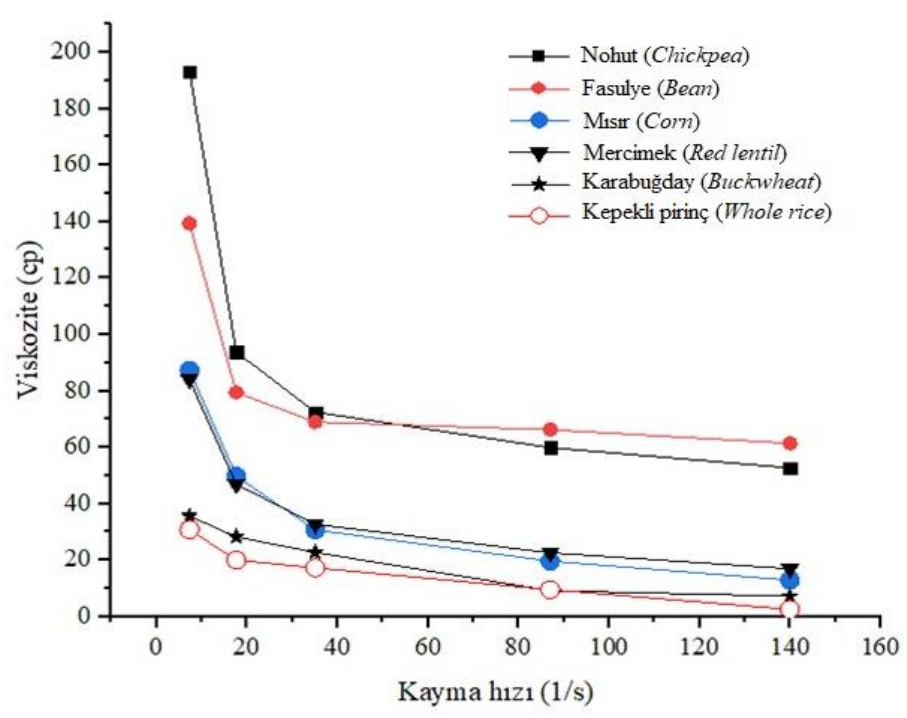

(b)

Şekil 2. Tarhana çorba örneklerinin rotasyonel hızına karşıllk viskozitelerindeki değişim (a), kayma hızına karşıllk viskozitelerindeki değişim (b)

Figure 2. Viscosity of tarbana soup samples versus to rotational speed (a), Viscosity of tarhana soup samples versus to shear rate

G1dalara fonksiyonellik kazandırmak veya gidayı zenginleștirme amacıyla katılan maddeler gıdanın tüketilebilirliğini olumsuz yönde etkilememeli, duyusal özelliklerini tüketici açısından bozmamalıdır (Eyidemir, 2006). Bu çalışmada duyusal analiz yapılmasının sebebi, geleneksel bir üründe daha önce kullanılmayan tahıl ve baklagil unlarının ilavesi sonucu ortaya çıkan yeni tarhana numunelerinin tüketiciler tarafindan kabulünü belirlemektir. Kuru tarhana örneklerinden hazırlanan çorbaların duyusal değerlendirme sonuçları Çizelge 4.'de verilmiştir.

Çizelge 4'de görüldüğü üzere test edilen koku, renk ve tat kriterleri bakımından örnekler arasında önemli farklılıklar tespit edilmezken $(P>0.05)$, kıvam ve ekşilik kriterleri açısından önemli fark $(P$ $<0.05)$ elde edilmiştir. Genel beğeni puanları açısından karabuğday diğer örneklerden yüksek iken, kepekli pirinç daha düşük bulunmuş. Ancak tarhana örneklerinin genel kabul edilebilirlik puanları arasındaki fark istatistiki açıdan önemsiz olarak değerlendirilmiștir $(P>0.05)$. Hiçbir tarhana örneğinin 6'nın altında puan almamış olması, farklı un kullanımının tüketici beğenisini olumsuz yönde etkilemediği şeklinde yorumlanmıştır. Tarhanada kullanilan tahil ve baklagil unlan, tarhana formülasyonunda yer alan yoğurt, sebze ve baharatlar gibi malzemelere göre daha nötr tada sahip hammaddelerdir. Aynı zamanda tarhana, tuz içeriğine sahip ve fermentasyona tabi tutularak $\mathrm{pH}$ değeri 4.0-4.5 düzeyine kadar düşürülen asidik bir gidadır. Dolayısıyla tarhana örneklerinin ana tat profilini, fermantasyonu sonucu oluşan organik asitler, tat ve aroma maddeleri ile formülasyona katılan baharatlar, sebzeler ve yoğurt belirlemekte, un tadı ise geri planda kalmaktadır. Dolayısıyla duyusal analiz sonucu, panelistlerin tarhanalar arasında istatistiki önem düzeyinde fark tespit edememesinin $(P>0.05)$ nedeninin, un tat ve kokusunun, tarhana lezzet profilinde geri planda kalmasından kaynaklandığı söylenebilir. 
Çizelge 4. Tarhana çorbalarının duyusal özellikleri

Table 4. Sensory properties of tarbana soup samples

\begin{tabular}{lcccccc}
\hline $\begin{array}{l}\text { Tarhana } \\
\text { Tarbana }\end{array}$ & $\begin{array}{c}\text { Koku } \\
\text { Flavor }\end{array}$ & $\begin{array}{c}\text { Renk } \\
\text { Color }\end{array}$ & $\begin{array}{c}\text { Kivam } \\
\text { Consistency }\end{array}$ & $\begin{array}{c}\text { Tat } \\
\text { Taste }\end{array}$ & $\begin{array}{c}\text { Ekssilik } \\
\text { Sourness }\end{array}$ & $\begin{array}{c}\text { Genel } \\
\text { Overall }\end{array}$ \\
\hline $\begin{array}{l}\text { Karabuğday } \\
\text { Buckwheat }\end{array}$ & $8.29 \pm 0.76$ & $7.43 \pm 1.27$ & $7.14 \pm 1.21$ & $7.57 \pm 1.27$ & $6.43 \pm 1.62$ & $8.00 \pm 1.00$ \\
$\begin{array}{l}\text { Kepekli pirinç } \\
\text { Whole rice }\end{array}$ & $6.43 \pm 2.23$ & $5.71 \pm 1.60$ & $6.29 \pm 0.76$ & $6.71 \pm 1.98$ & $5.29 \pm 0.95$ & $6.43 \pm 1.40$ \\
$\begin{array}{l}\text { Mercimek } \\
\text { Red lentil }\end{array}$ & $6.57 \pm 1.51$ & $7.00 \pm 1.00$ & $6.29 \pm 1.25$ & $6.29 \pm 1.11$ & $7.29 \pm 0.95$ & $7.00 \pm 1.15$ \\
$\begin{array}{l}\text { Fasulye } \\
\text { Bean }\end{array}$ & $7.29 \pm 0.95$ & $6.14 \pm 2.04$ & $6.57 \pm 0.79$ & $8.00 \pm 1.15$ & $7.43 \pm 1.62$ & $6.57 \pm 1.62$ \\
$\begin{array}{l}\text { Misır } \\
\text { Corn }\end{array}$ & $7.71 \pm 1.11$ & $7.14 \pm 1.21$ & $8.29 \pm 0.76$ & $6.57 \pm 1.72$ & $8.00 \pm 1.00$ & $7.00 \pm 1.15$ \\
$\begin{array}{l}\text { Nohut } \\
\text { Chickpea }\end{array}$ & $8.29 \pm 0.76$ & $7.71 \pm 1.11$ & $7.14 \pm 0.90$ & $7.71 \pm 1.11$ & $8.29 \pm 1.11$ & $7.43 \pm 1.27$ \\
\hline $\begin{array}{l}P \text { değeri* } \\
P \text { value* }\end{array}$ & 0.072 & 0.091 & 0.007 & 0.171 & 0.004 & 0.215 \\
$\begin{array}{l}* P<0.05 ; \text { örnekler arasinda istatistiksel olarak önemli fark olduğunu göstermektedir. } \\
* P<0.05 ; \text { indicates that there is a significant difference between the samples. }\end{array}$ & & & \\
* & & & & &
\end{tabular}

\section{TARTIŞMA}

$\mathrm{Bu}$ çalışmada günlük diyetimizin $\% 70^{\prime}$ lik bölümünü olușturan baklagil ve tahıllardan elde edilen unların, geleneksel bir gidamız olan tarhana üretiminde buğday unu yerine kullanımı değerlendirilmiş ve elde edilen ürünlerin bazı fizikokimyasal, mikrobiyolojik ve duyusal nitelikleri belirlenerek karşılaştırılmıstır. Tarhana numunelerinin incelenen nitelikler açısından, kullanılan un çeşitliliğinden önemli ölçüde etkilendikleri, un çeşidinin tarhana özellikleri üzerinde belirleyici olduğu tespit edilmiştir. Kullanilan unlar ve bunlardan elde edilen tarhana örnekleri karşılaştırıldığında ise formülasyonuna katılan yoğurt, baharat ve sebzelerin etkisiyle fizikokimyasal nitelikler açısından tarhanaların yağ, protein ve karbonhidrat değerlerinde artış olduğu tespit edilmiştir. Un çeşitliliğine bağlı olarak yaş tarhana ve toz tarhana örneklerinin renk değerlerinde farklılık gözlenmiştir. Tarhana örneklerinde uygulanan kurutma prosesinin ise toplam mikrobiyotanın canlılı̆ında azalmaya neden olduğu ancak toz tarhanalarda canliliğın devam ettiği belirlenmiştir. Elde edilen ürünlerin en önemli niteliği tüketici kabulüdür ki, yapılan duyusal değerlendirme sonucu tüm numunelerin panelistler tarafindan yeterli puanı alması farklı un kullanımının tüketici beğenisini olumsuz yönde etkilemediğini göstermiştir.
Bu çalışma ile geleneksel fermente gida ürünümüz tarhana, günlük diyetimizde yer alan kırmızı mercimek, pirinç, misır, nohut, fasulye ve karabuğday gibi alternatif unlarla üretilerek alternatif bir gida ürünü haline getirilmiştir. Kullanılan mercimek, nohut, pirinç, fasulye ve misır unlarında gluten olmaması bu ürünlerin çölyak hastaları tarafindan da kullanılabilir bir alternatif olmasını sağlamıştır. Pirinç ununun ise kepekli olarak ögütülmüss olması lif içeriğinin zenginliği açısından farklı bir fonksiyonellik oluşturmaktadır. $\mathrm{Bu}$ çalışma ile elde edilen ürünlerin günümüz tüketicisinin fonksiyonel, doğal ve besinsel niteliği yüksek ürün arayışına alternatif olacağı düşünülmektedir.

\section{TEŞEKKÜR}

$\mathrm{Bu}$ çalışma Kastamonu Üniversitesi Bilimsel Araştırma Projeleri Koordinatörlüğ̈ tarafindan desteklenmiştir (Proje No:KÜBAP-01/2018-40). Yazarlar desteklerinden dolay1 Kastamonu Üniversitesi BAP Koordinatörlüğüne teşekkür ederler.

\section{KAYNAKLAR}

AACC, (2000). American Association of Cereal Chemists: Approved Methods of the AACC ( $8^{\text {th }}$ ed.), The Association: St. Paul, MN. 
Anonim, (2004). TSE 2282 Tarhana Standard1, Türk Standartları Enstitüsü, Ankara.

Bilgiçli, N.,Ibanoglu, Ş. (2007). Effect of wheat germ and wheat bran on the fermentation activity, phytic acid content and colour of tarhana, a wheat flour-yoghurt mixture. J.Food Eng., 78: 681-686.

Bilgiçli, N. (2009a). Enrichment of gluten-free tarhana with buckwheat flour. Int. J. Food Sci. Nutr., 60(4):1-8.

Bilgiçli, N. (2009b). Effect of buckwheat flour on chemical and functional properties of tarhana. LWT-Food Sci.Technol.,42(2):514-518.

Dağlıoğlu, O. (2000). Tarhana as a traditional Turkish fermented cereal food, its recipe, production and composition. Nabrung, 44(2):8588.

Dağlıoğlu, O., Arıcı, M., Konyalı, M., Gümüs, T. (2002). Effects of tarhana fermentation and drying methods on the fate of Escherichia coli O157:H7 and Staphylococcus aureus. Eur.Food Res.Technol., 215:515-519.

Dayısoylu, K.S., Gezginç, Y., İnanç, A.L. (2003). Kahramanmaraş tarhanasına besin fonksiyonelliği açısından bir bakış. 3. Gıda Mühendisliği Kongresi, 511-523, Ankara.

Duran, T. (2017). Buğday kepeği ve şeker pancarı lifinin tarhana kalitesine etkisi. Yüksek Lisans Tezi, Aksaray Üniversitesi, Fen Bilimleri Enstitüsü, Aksaray.

Erbaş, M.,Certel, M., Uslu M. K. (2005). Microbiological and chemical propertiesof Tarhana during fermentation and storage as wetsensorial properties of Tarhana soup. LWT, Food Sci.Technol.,38:409-416.

Erkan, H. (2004). Farklı tahil unları kullanılarak üretilen tarhana örneklerinin kimyasal, fonksiyonel ve duyusal özelliklerinin araştırılması. Doktora Tezi, Hacettepe Üniversitesi, Fen Bilimleri Enstitüsü, Ankara

Erkan, H., Celik, S., Bilgi, B., and Koksel, H. (2006). A new approach for the utilization of barley in food products: Barley tarhana. Food Chem., 97(1):12-18.
Eyidemir, E., (2006). Kayısı çekirdeği ilavesinin eriştenin bazı kalite kriterlerine etkisi. Yüksek Lisans Tezi, İnönü Üniversitesi, Fen Bilimleri Enstitüsü, Malatya.

Geankoplis, C.J. (1983). Transport Processes and Unit Operation ( $3^{\text {rd }}$ ed.). New Jersey: PTR Prentice-Hall, 923p.

Göçmen, D., Gürbüz, O., Şahin, İ. (2003). Hazır tarhana çorbaları üzerinde bir araştırma. GID $A$, 28:13-18.

Güney Funda, E., (2009). Ülkemizde tüketilen tarhanaların mikrobiyolojik ve bazı kimyasal özelliklerinin analizi. Yüksek Lisans Tezi, Anadolu Üniversitesi, Eskişehir.

Hayta, M., Alpaslan, M., Baysar, A. (2002). Effect of drying methods on functional properties of tarhana. A Wheat Flour-Yoghurt Mixture. J.Food Sci., 67(2):740-744.

Hendek Ertop, M. (2017). Farklı fermantasyon ve kurutma yöntemleriyle üretilmiş toz ekşi hamurun bazı mikrobiyolojik nitelikleri ve ekmekteki küf gelişimi üzerine etkileri. GID A, 42(5):609-619.

Hendek Ertop, M.,Cerit, Z.G., Atasoy, R. (2019). Evaluation of physicochemical, nutritional and sensory properties of the wet tarhana. Food Sci. Qual. Manag., 83:61-67.

İbanoğlu, S.., Ainsworth, P., Wilson, G., Hayes, G.D. (1995). The effect of fermentation conditions on the nutrients and acceptability of tarhana. Food Chem.,53(2):143-147.

Kitan, S. (2017). Glutensiz tarhana üretiminde kinoa (Cenopodium quinoa) kullanımı. Yüksek Lisans Tezi, Fen Bilimleri Enstitüsü, Ondokuz Mayıs Üniversitesi, Samsun.

Kohajdová, Z.,Karovičová, J., Magala, M. (2013). Effect of lentil and bean flours on rheological and baking properties of wheat dough. Chem. Pap., 67(4):398-407.

Köse, E., Çağındı, Ö.S. (2002). An investigation into the use of different flours in tarhana. International J. Food Sci. Technol., 37:219-222.

Kumral, A. (2015). Nutritional, chemical and microbiological changes during fermentation of 
tarhana formulated with different flours. Chem. Cent J., 9:16. doi:10.1186/s13065-015-0093-4.

Nes, I.F., Diep, D.B., Havarstein, L.S., Brurberg, M.B., Eijsink, V., Holo, H. (1996). Biosynthesis of bacteriocins in lactic acid bacteria. Antonie Leeuwenhoek, 70:113-128.

Özçelik, F.,Cakıroglu, P., Surucuoglu, M. S.(1997). Çocukların anne sütü ile beslenme suresi ve ek besinlere başlama durumları. Gıda, 22:123127.

Özdemir S.,Gocmen D., Yildirim Kumral A. (2007). A traditional Turkish fermented cereal food: Tarhana. Food Rev. Int., 23:107-121.

Öner, M.Ö., Tekin, A.R., Erdem, T. (1993). The use of soybeans in the traditional fermented foodtarhana. LWT-Food Sci. Technol., 26(4):371-372.

Özmen, F.H. (2011). Çölyak hastaları için baklagil unları ile zenginleştirilmiş pirinç tarhanası. Yüksek Lisans Tezi, Hacettepe Üniversitesi, Fen Bilimleri Enstitüsü. Ankara.

Siyamoğlu, B. (1961). Türk Tarhanalarının Yapilısı ve Terkibi Üzerine Bir Araştırma. Ege Üniversitesi, Ziraat Fakültesi Yayınları, İzmir, 77s.

Şimşek, Ö., Özel, S., Çon, A.H. (2012). Ev ve işletme tipi uşak tarhanası hamurlarında fermantasyon sürecine ait mikrobiyolojik ve kimyasal özelliklerin karşılaştırılması. Gıda, 37(6):341-348.

Tamer, C.E., Kumral, A., Asan, M., Sahin I. (2007). Chemical compositions of traditional tarhana having different formulations. J. Food Process. Preserv.,31:116-26.

Tarakç1, Z., Anıl, M., Koca, I., İslam, A. (2013). Effects of adding cherry laurel (Laurocerasus officinalis) on some physicochemical and functional properties and sensorial quality of tarhana. Qual. Assur. Saf. Crop. Foods, 5(4):347-355.

Temiz A.,Pirkul T. (1991). Chemical and sensorial properties of tarhana samples produced with different components. GIDA, 16(1):7-13.

Yörükoğlu, T. (2012). Maraş tarhanasının bazı özelliklerinin belirlenmesi. Yüksek Lisans Tezi, Kahramanmaraş Sütçü İmam Üniversitesi, Fen Bilimleri Enstitüsü. Kahramanmaraş.

Yücecan, S., Kayakırılmaz, K., Başoğlu, S., Tayfur, M. (1988). Tarhananın besin değeri üzerine bir araştırma. Türk Hijyen ve Deneysel Biyoloji Dergisi, 45(1):47-51. 